\title{
The Relationship Between Corporate Reputation and PuRchase Intention Among Starbucks' Muslim Consumers in Malaysia
}

\author{
Romlah llias \\ Universiti Putra Malaysia \\ romlahilias88@gmail.com \\ Rosya Izyanie Shamshudeen \\ Universiti Putra Malaysia \\ rosya@upm.edu.my \\ Jusang Bolong \\ Universiti Putra Malaysia \\ jusang@upm.edu.my \\ Nik Farhan Mustapha \\ Universiti Putra Malaysia \\ farhan@upm.edu.my
}

\begin{abstract}
Starbucks has been ranked number one in the food and beverage industry in Malaysia and able to secure many branches throughout the country. Although Starbucks had faced halal certified issue among Muslim consumers in Malaysia, this company is able to survive and to provide excellent services to Malaysian community, including the Muslims. With regard to this, a study has been conducted to determine the relationship between reputation elements (products and services, customers' orientation, social responsibilities of Starbucks, positive feeling of people, leadership and innovation and ethical of Starbucks) on Muslim consumers' purchase intention. The data were collected from surveys done on 380 Starbucks' customers in Putrajaya. The result showed that all of the elements of corporate reputation had imposed a significant and strong relationship on purchasing intention of customers. Specifically, positive feeling is the most important element $(r=0.686)$ in corporate reputation that shows the strongest relationship with purchase intention. Interestingly, the element of religion shows a positive and strong relationship $(\mathrm{r}=$ 0.591), but it has the lowest relationship compared to other elements. A number of recommendations have been made and it is hoped that interested parties would use them to improve and enhance their corporate reputation to achieve their consumers' target.
\end{abstract}

Keywords: corporate reputation, purchase intention, Starbucks, Muslim consumers 


\section{INTRODUCTION}

Coffee consumption in Malaysia has become very popular, as coffee became one of the common choices for beverage (Yee, Mun, Yee \& Ling, 2014). There are many noticeable coffee outlets in towns and cities since the last few years and there is a strong traction of a hot cup of coffee among professionals and the young (Lee, 2007). This phenomenon also lead to the booming of the coffee cafes in Malaysia such as Old Town, McCafe, Gloria Jeans, Dome, Starbucks, Coffee Bean and Tea Leaf (Hashim, Ruslan \& Haque, 2015). Currently, Starbucks is recognized as the leading specialty coffee company with 215 stores in Malaysia (Starbucks News Room, 2018). The first Starbucks store opened in 1998 and has been expanding to Sabah and Sarawak. Its immense popularity brought Starbucks Malaysia to introduce their first drive-thru concept store in December 2009 in Johor Bahru. Besides that, they opened their first suburban store in 2012 at Seri Manjung, Perak. To date, Starbucks has 24 drivethru concept stores penetrating Perak, Johor, Pahang, Penang and also Klang Valley area (Berjaya Food Berhad, n.d).

Coffee consumption at Starbuck and Coffee Bean has been regarded as a normal routine for the urban Muslim society and regardlessly applies to the Kopitiams of local based and Chinese coffee shops as well (Hamzah, 2010; Abdul Karim 2010). In brief, it has become a norm to Malaysian Muslim with a high standard of living in the city to consume coffee nowadays (Abd. Razak, 2009). The blooming of coffee stores in Malaysia as mentioned above encourage this attitude of Malaysia Muslim. For many years, coffee drinking has been part and parcel of Malaysian culture. With the growing coffee stores nationwide, customers become more sophisticated in choosing the best quality of coffee in their daily life and Starbucks has become the top choice of consumers compared to Coffee Bean, San Francisco and other preferred brands (Goi, 2013). One of the reasons of this situation is the strong corporate reputation held by Starbucks itself since the introduction of the company in Malaysia in 1998.

Hence, to maintain their strong position, Starbucks need to strengthen their corporate reputation. A mutual judgement of a company's ability to give valued outcomes to a representative set of stakeholders is characterised as corporate reputation (Fombrun et al., 2000). In addition, Walsh and Beatty's (2007) view of customer-based corporate reputation is the firm's services, products, communication activities, corporate activities and the interactions with the firm (customers, employees, management) will affect customer's overall evaluation towards the firm. In this regard, reputation can be defined as the key stakeholders' perceptions towards a company's service, employees, customers, and communicative actions, as well as the consequence of corporate activity over time in the minds of the stakeholders (Feldman et al., 2014). Corporate reputation is imperative for the company in order to shrink transaction costs, and also to influence the financial and customer outcome variables such as consumer trust and loyalty (Doney \& Cannon, 1997). The strong trust towards the company will affect the perception of the consumers towards the company's corporate reputation.

A hot topic in recent years, corporate reputation ascertains one of the most positive outcomes of doing the right thing is a good reputation. The recognition that gained by Starbucks for being listed as fifth most admired company in the world and number one in worldwide food industry (Starbucks News Room, 2018) shows that Starbucks has a good corporate reputation. Some studies examine corporate reputation from the customers perspective (Walsh \& Beatty, 2007), and perspective of employees (Davies \& Chun, 2009).

A great number of studies have looked at Muslim consumers from various perspective, such as tourism industry (Eid, 2015), business context/strategy (Yaacob, 2014), banking (Awan 
\& Bukhari, 2011). Religion, being the significant basis in Muslim customers' lives, (Essoo \& Dibb, 2004; Shachar et al. 2011), also emphasizes on the purchase intention of products, especially food and beverages which are more related to the religious beliefs. Considering halal is so important to Muslims in terms of their food consumption, there have been a lot of studies on this concern in recent years (e.g.: Mohamed, Rezai, Shamsudin \& Chiew, 2008).

Starbucks' solid corporate reputation has attracted more customers, which has helped the firm maintains its profit and income. Superior performance over a period of time is the foundation of a positive corporate reputation. Customers' confidence and risk perceptions can be improved when they make decisions about an organization's performance and the quality of its products and services, as confidence is an important factor in the establishment of relational trust (Morgan \& Hunt, 1994).

There are five crucial factors to determine a good corporate reputation such as the employees, company's ethics, leadership, financial performance, social responsibility, management and focus on quality, consumers, emotional appeal, reliability and communications (Ljubojcvic \& Ljubojcvic, 2008). These factors are considered as important factors because of the latest information gathered by Ljubojcvic \& Ljubojcvic (2008) compared to Walsh and Beatty which is in 2007 and it covered overall aspects of corporate reputation while Walsh and Beatty (2007) only focus on the stakeholders. On the other hand, Feldman, Bahamonde, and Velasquez (2014) proposed eight elements of corporate reputation, but one element is not suitable for measuring at the consumer's level, which is the company with a good workplace environment.

The desire for customers to buy products from a particular shop or a particular brand, can be defined as customers' purchase intention and it also can describe the customer's loyalty (Juhl et al., 2002). There are a few factors that influence the purchase intention of the customers such as value, satisfaction and quality that can directly affect the customer's behavioural intention (Joseph et al. 2000). Consumers' purchasing intent, attitude toward the company and its products, and brand loyalty are all boosted by a good corporate reputation (Brown, 1997; Saxton, 1998). While Spreng and Page Jr. (2001) opined that consumers' brand attitudes are proven to be influenced by business reputation, which in turn affects their satisfaction, purchase intention, and perception of firm performance.

Even the corporate reputation of Starbucks was good and well accepted, but lately there are some issues that can be related to the corporate reputation of Starbucks. The disclosure of the products served in Starbucks was certified as 'Halal, but it has stirs consumer's attention as it has been labelled as 'Haram'. This has touched the sensitivity of Muslim around the world and it was alarming to the consumers in Malaysia (JAKIM, 2010). This halal status has been debated in the Parliament. According to Astro Awani (2014) titled 'Sijil Halal Starbucks Tidak Pernah Ditarikh Balik - JAKIM' (Starbucks Halal Certificate is Never Revoked - JAKIM), public makes countless phone calls to the Halal Hub Division, Malaysian Islamic Development Commission (JAKIM) to get confirmation on the Halal certified status of Starbucks products. This situation causes doubtful status of drinks and foods offered by Starbucks to the Muslim consumers. A worried client tweets about receiving an SMS from JAKIM alleging that all chocolate and vanilla flavours used in Starbucks beverages contained E471, (mono diglycerides of animal origin [pork]), as well as the Rasberry Frap had cherries soaked in alcohol which made the issue went viral (Lian, 2011). 
The complained of the halal status has created chaos and being spread on social media (Lian, 2011). The rumours about this issue was not new and has been on commotion since 2016. Starbucks Malaysia has answered all the enquiries regarding the Halal status of their products in their official Facebook page to clear the air to all their customers. They informed that all their foods and beverages offered at Starbucks Coffee Stores in Malaysia are halal and can be consumed by Muslim consumers without doubt as they have been certified Halal by JAKIM. Starbucks took the initiative to clarify this issue by inviting all their customers to ask any questions on their Facebook page.

The controversy over the halal status of Starbucks products began in 2011 and has continued to this day, despite the fact that Starbucks has clarified the halal status of its products. In fact, JAKIM also has released statement about this issue. The fake information has affected Starbucks' corporate reputation in two ways; whether it can strengthen the company or can reduce the company's strength. The intention of consumers to buy Starbucks's product will elevate the Starbucks's profit and strengthen their corporate reputation. Apart from the halal issue, Starbucks still gain the recognition for being listed as the fifth most admired company in the world and number one in worldwide food and beverage industry (Starbucks News Room, 2018).

In addition, Starbucks Coffee Malaysia also earn top honours as an employer of choice for their employment practices at the Aon Hewitt Best Employers of 2015 Awards. Employee's strong engagement, high-performance culture, compelling brand and effective leadership lead to the recognition of Starbucks as a high corporate reputation company. Consumers' preference for Starbucks' products, despite the controversy, demonstrates that Starbucks has established a good corporate reputation in terms of products and services. Among other brands, which is Coffee Bean, San Francisco and other brands, Starbucks becomes the favourite among consumers (Goi, 2013) and this clearly leads to the corporate reputations of Starbucks itself that contribute to the purchase intention of Muslim consumer. This clearly emphasizes that consumers still have a positive perception of Starbucks, despite the fact that the company has had halal certification issues in the past.

Based on the above discussion, this study aims to determine the relationship between reputation elements (products and services, customers' orientation, social responsibilities of Starbucks, generate positive feeling of people, leadership and innovation and ethical of Starbucks) on Muslim consumers' purchase intention. This study is significant in several ways. Firstly, it contributes to the body of knowledge on the relationship of corporate reputation and purchase intention, especially on the important elements that contribute to purchase intention among Muslim Starbucks customer. Furthermore, this research can serve as a guidance for other companies in Malaysia, particularly those in beverage and food industry looking to expand their business in terms of perception on consumer towards their corporate reputation. The perception of Muslim consumers towards Starbucks Corporate reputation is one of the contributing factors to the success of Starbucks as the Coffee café leader in Malaysia. Starbucks could improve their corporate reputation in order to achieve a positive perception among their customers, which would result in more profits for the company in the future.

\section{LITERATURE REVIEW}

Fombrun (1996) defines corporate reputation as " a perceptual representation of a company's past actions and future prospects that describes the firm's overall appeal to all of its 
constituents when compare with other leading rivals" while corporate reputation is defined as a stakeholder's evaluation of a company over time. Gotsi \& Wilson (2001) discovered the company's appraisal based on stakeholders' experiences, other forms of communication and symbols about the corporation and its actions, and comparisons with other competitors. Corporate reputation, according to Fombrun et al. (2000), is a social construct describing the aggregate perceptions of different stakeholders about a company's performance. The most important stakeholders for most businesses to consider are customers, distributors and retailers, suppliers, joint venture partners, financial institutions and analysts, shareholders, government regulatory agencies, social action organisations, the general public, and employees (Gray \& Balmer, 1998).

Stakeholders' motivation to give or retain support will be influenced by the organization's reputation. Herbig and Milewicz (1993) claimed that reputation as an estimation of the consistency over time of an attribute of an entity and the attributes that contribute to various type of reputation of the company such as price, product quality, management quality and innovativeness. Subsequently, if its customers foster a negative impression of the organization or its items, its deals and benefits will definitely drop (Gray \& Balmer, 1998). In other words, the purchase intention of customers to buy the product from the company that have positive corporate reputation is higher compared to the company that have negative corporate reputation (Gatti et al., 2012). If a company's reputation is strong, consumers will give highly regarded companies the opportunity to correct their mistakes, which consumers are unlikely to give to a less regarded company (Sibthorpe, 2009).

Within the theory of planned behaviour, the usefulness of the attitudinal operationalization of corporate reputation and whether corporate reputation leads to behavioural an intention, which is purchase intention of consumers towards firm's products and services, must be determined. Hence, it is critical to investigate customers' attitudes toward corporate reputation and the impact of those attitudes on purchase intent because they are one of the most important primary stakeholders (Shamma \& Hassan, 2015).

Religious belief is regarded as the most important cultural forces in moulding human behaviour (Cukur et al. 2004; Duriez et al. 2004; Lau 1989; Kotler, 2000). Previous literature on food and beverages and its relationship to purchase intention, Islamic knowledge and awareness is regarded as important factors. Conferring to Mohammed et al. (2008), the Malaysian government's halal logo has a significant impact on respondents' awareness of food products. Other research suggests that halal labelling is important in consumers' decision on buying a product (Latiff et al., 2015). Latiff's study also indicates that Malaysian consumers' purchasing intentions are strongly linked to halal certification, nutritive value, and ingredient used.

The perceived product quality has a positive effect on corporate reputation (Weigelt \& Camerer, 1988). The evaluation of products and services by consumers, which influences their attitudes toward the product/brand and purchase intent, is referred to as perceived quality. (Pappu et al. 2005). According to past studies, higher perceived quality leads to a positive brand attitude (Johnson et al. 2006; Monirul \& Han 2012). Several researches indicate that perceived quality has a positive direct effect on consumer's purchase intentions (e.g.: Carman, 1990; Parasuraman et al., 1998). In other words, customers who perceive a high quality offering have a higher intention to buy a product than those who perceive a low quality offering (Gatti, Caruana, \& Snehota, 2012). 
Similar to product quality, service quality is one of the most successful factors in the firm in order to differentiate themselves from other competitors (Maiyaki, 2013). Customers' intentions to purchase services offered by a particular organisation can be influenced by the attitudes and services provided by its employees. The services showed positive identification of that company and it reflected the positive corporate reputation as well (Dutton et al., 1994). A high level of service quality will increase customer's retention also attracting new customers. It also can enhance the company's corporate image, reduced cost, positive word-of-mouth recommendation and also enhanced profitability (Cronin et al., 2000; Yoon \& Suh, 2004).

There are many studies in corporate social responsibility (e.g. Logsdon \& Wood, 2002; Rettab, Brik, \& Mellahi, 2009; Roberts, 2003; Van der Laan, et al, 2008) that emphasize responsibility as a key driver of corporate reputation. Fortune's Corporate Index cited in Fombrun and Shanley (1990) mentioned the social and environmental responsibility to determine the reputation survey. This shows that corporate social responsibility and corporate reputation rely on each other strongly. In other words, the Corporate Social Responsibility activities have an impact on profitability as well. It will improve the firm's reputation and legitimacy while also making a positive contribution to society.

In this study, Starbucks must pay special attention to the halal status of their products because they have Muslim customers who buy their products. There are a few Starbucks branches at Muslim countries such as Indonesia, Saudi Arabia, Brunei Darussalam, Pakistan and others. The study by Bronn and Vidaver-Cohen (2009) also shows this social initiative will gain 'reputational capital' and 'by doing good' it also can improve the ability of the company to attract resources, build competitive advantage and enhance performance.

Purchase intention means the agreeable situation of consumers to make a transaction with retailer and it could be defined as an attempting to make a purchase of products or service (Dodds et al, 1991). In purchasing situation, these elements have strong relationship with the intention to purchase a service, to the attitude of buyers to salespersons and products. For example, the company's reputation in US was affected by the intention of corporate customers in their insurance's purchases (Yoon et al, 1993). Hence, this study will focus more on the elements of corporate's reputation that attracts the purchase intention of consumers of Starbucks Malaysia. According to Juhl et. al. (2002), the desire of consumers to buy product from selected shop is best represented by customer's purchase intention and it also can describe the customer's loyalty towards that product. The factors that affect the attitude towards buying product are strong relationship with intention to buy such as the certainty, perceived consumers effectiveness and sustainability (Joseph et. al., 2000).

Customers are becoming more sophisticated in their selection of the best quality of coffee in their daily lives, and there are a few factors that influence their decision like brand image, social influence and socioeconomic factors (Davis, 1999). The purchase intention also depend on others factors which include the satisfaction, value, quality that can be directly impacted the behavioural intention (Joseph et. al., 2000). The quality of the product is the first elements of measurement of corporate reputation (Helm, 2005). Thus, the quality of the products offered by Starbucks has led to the purchase intention of their products.

Akbar (2009) cited in Samad (2014) stated that purchase intention is related to customer's attitude. According to Fishbein and Ajzen (1975), the definition of attitude can be concluded as the evaluative effect of individual to perform a particular behavior whether it is positive or negative. The attitude of the customers towards specific behavior is influenced by the 
intention of that customer to perform that specific behavior (Balla \& Ibrahim, 2014). There are three attributes of consumers' attitude that affect consumers' purchase intention stated by Jaafar et al. (2012). The study only concluded about the consumers' attitudes which include perceived economic situation, familiarity, and trust as well as the price that influences the consumers' purchase intentions.

The perception of Muslim consumers towards Starbucks product will decide their intention on repurchasing from the company. The signal for the actual purchase is best in defining the behavioural intention of consumers (Parasuraman, Zeithaml \& Berry, 1998). This includes the willingness to pay for premium price, purchase intention and this is much related with the performance of the company. The customers that have the minimum sensitivity to price changes and will stay longer with the service provider are the customers that have higher purchase intention and the willingness to pay for premium price (Keh \& Xie, 2009).

Customer's orientation refers to the willingness of company's personnel to meet customer needs (e.g.: Brown et al., 2002). In addition, customer's orientation is associated with the assumption that a company will put its customers at the centre of its strategic emphasis, and that the company will endeavour to assist their consumers in making buying decisions that lead to customer's pleasure (Saxe \& Weitz, 1982). Customer's orientation enables businesses to efficiently monitor and improve how well they have satisfied customer's demands, resulting in higher customer's satisfaction and loyalty by giving superior value to the buyer (Chang \& Zhu, 2011).

Ethical considerations are critical in any business, especially when it comes to gaining the trust of stakeholders. When that trust is broken, a variety of negative consequences might occur, including increased government regulations, contentious suppliers, and disillusioned customers (Creyer, 1997). Consumers, for example, have organised boycotts to oppose what they see as unethical or irresponsible company activity (Creyer, 1997).

From the discussion, this study will be discussing on seven elements of corporate reputation in this study which is in term of religion responsibility, product and services, customer's orientation, the ability to generate positive feeling in people, leadership and innovation, ethical and social responsibility.

\section{METHODOLOGY}

Quantitative approach was used in this study based on the cross-sectional survey design. Wilayah Persekutuan Putrajaya was chosen as the location for this study because 97.4 percent of the population is Muslim (Department of Statistics Malaysia, 2017) and the customers who visit Starbucks branches, particularly those in Putrajaya, are predominantly Muslim. On average, the population size of those who visit Starbucks in a year is estimated to be between 36,000 and 54,000 . So the minimum number $(36,000)$ is counted as customers' populations for the study, with the sample size decided by convenience sampling is 380 (Krejcie \& Morgan 1970).

The data for this study was gathered quantitatively, and the instrument was created based on previous research and literature reviews. There are three parts of the questionnaire. It includes different personal demographic variables, elements of Corporate Reputation and the level of purchase intention. The eight elements highlighted are (1) religion and responsibility, (2) products and services, (3) customer orientation (4) positive feeling in people, 
(5) leadership and innovation, (6) ethical and 7) social responsibility. For these eight elements of Corporate Reputation's variable, there are 21 items to be answered by the respondents.

The data collection procedure of this study was done through drop and collect method. Out of 405 questionnaires that have been distributed, 380 questionnaires has been collected. The questionnaire employs six point Likert-type scaled questions with end points rating from (1) strongly disagree to (6) strongly agree.

\section{CONCEPTUAL FRAMEWORK}

The Theory of Planned Behaviour (TPB) aims to explain how certain attitudes are linked to certain behaviour intentions to undertake specific acts. In general, the stronger an individual's desire to engage in a specific behaviour, the more likely that person is to actually perform that behaviour. According to the TPB, there should be a positive relationship between attitudebased conceptualizations of corporate reputation and customer's intent to buy.

The following elements determine an individual's behavioural intentions in TPB: first, an individual's attitude toward the behaviour; second, the subjective norm surrounding the performance of such behaviour; and third, an individual's perceived behavioural control (PBC) (Ajzen, 1985, 1991). In this study, only the individual's attitude will be analysed through the element of corporate reputation. It is because the perceived social pressure by others and perceived control beliefs (Bang, Odio, \& Reio, 2014) does not being measured in this study. Corporate reputation is seen as an attitude that have the direct impact on intention to perform a certain behaviour that turn to be the actual behaviour in this conceptualization.

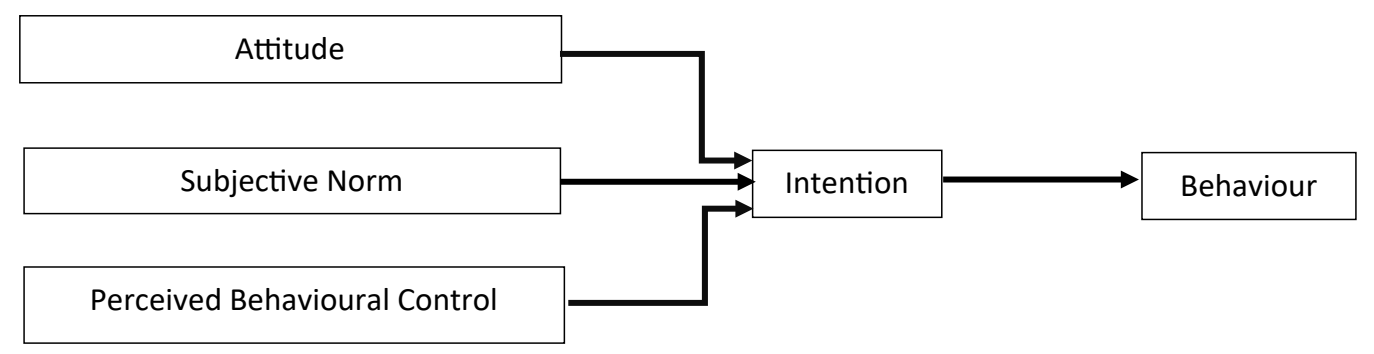

Figure 1:Theory of Planned Behaviour (Ajzen, 1991)

The relationship between consumers' intentions to buy and attitude-based measures of corporate reputation is expected to be positive where purchase intention depends on corporate reputation as perceived by customers. This study therefore investigates the relationship between elements of corporate reputation and consumers' purchase intention.

Based on the discussion on the adoption of the attitudinal conceptualization and operationalization as underlined in the Theory of Planned Behaviour model, this research's conceptual framework is formed to determine whether the relationship between the elements of corporate reputation and consumers' intents to buy is positive, where purchase intention is dependent on corporate reputation as perceived by customers. 


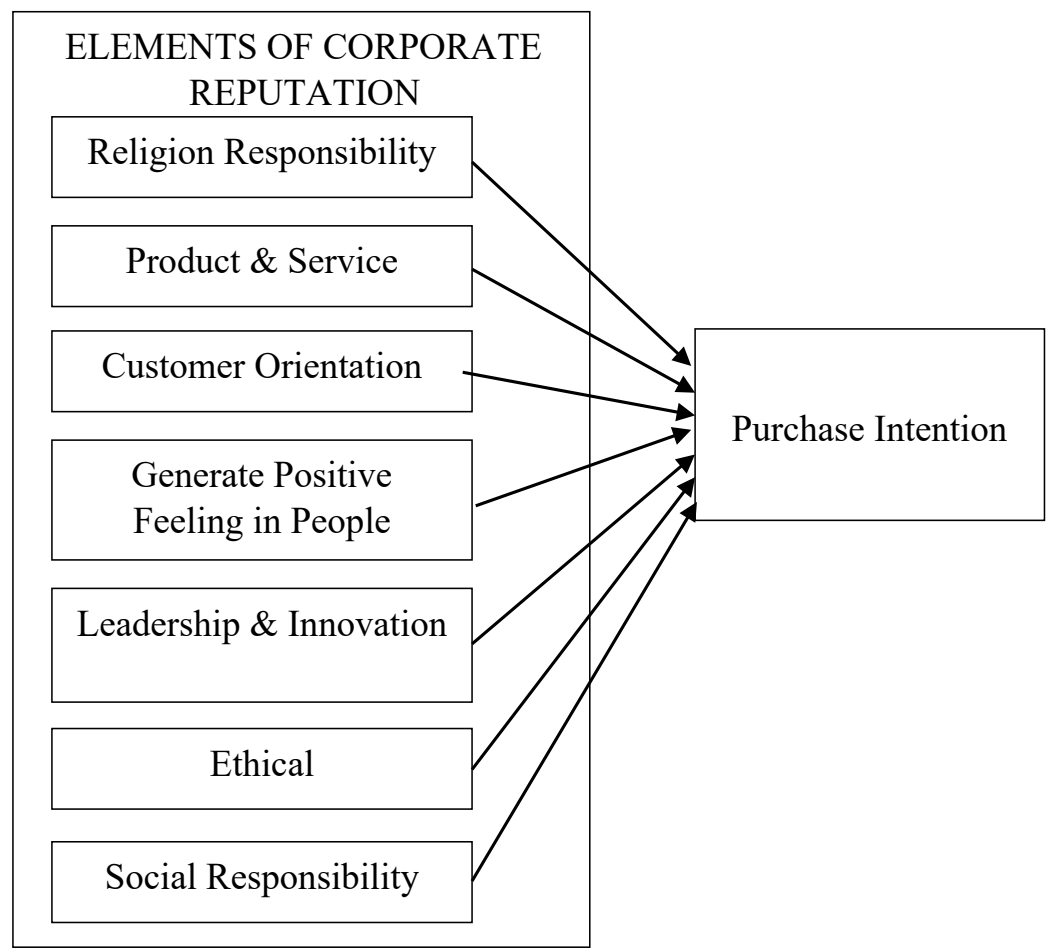

Figure 2: Conceptual Framework of The Study

\section{FINDINGS}

The relationship between elements of corporate reputation and purchase intention had been investigated using Pearson Correlation test. Based on Table 1, all corporate reputation elements have a positive and moderate correlation with purchase intention. The element of religion is directly related to purchase intention. The significant value for all of the independent variables, such as religious beliefs, products and services, and leadership and innovation, is 0.000 .

This result implies that all variables are statistically significant in affecting dependent variables. The findings revealed that all aspects of corporate reputation had a substantial and sturdy relationship with customer purchase intent. Specifically, the element of generate positive feeling is the most important elements $(\mathrm{r}=0.686)$ in corporate reputation that indicates the strongest relationship with purchase intention. However, the elements of religion still shows a positive and strong relationship $(r=0.591)$, but it is the weakest relationship when compared to the other elements. 


\section{Corporate Reputation and Purchase Intention}

\begin{tabular}{lcc}
\multicolumn{1}{c}{ INDEPENDENT VARIABLES } & PURCHASE INTENTION \\
\multicolumn{1}{c}{ Elements of Corporate Reputation } & $\begin{array}{c}\text { Correlation Coefficient } \\
(\mathbf{r})\end{array}$ & $\begin{array}{c}\text { Significant Value (p) } \\
\text { Religion }\end{array}$ \\
Products \& Services & 0.591 & 0.000 \\
Customer's Orientation & 0.633 & 0.000 \\
Generates Positive Feeling In People & 0.661 & 0.000 \\
Leadership \& Innovation & 0.686 & 0.000 \\
Ethical & 0.676 & 0.000 \\
Social Responsibility & 0.628 & 0.000 \\
\hline
\end{tabular}

\section{DISCUSSION}

The aim of this study is to determine the relationship between corporate reputation's elements (religious, products and services, customers' orientation, social responsibilities of Starbucks, generate positive feeling of people, leadership and innovation and ethical of Starbucks) on Muslim consumers' purchase intentions. The results of hypothesis testing revealed that all of the elements influence consumers' purchase intentions for Starbucks food and beverages.

This significant correlation of religious aspects gives the impression that when customers value religious aspects such as Islamic jurisprudence, this will guide them in determining their desire to purchase Starbucks' products. The responses are in line with the findings of Schifman and Kanuk (2009), who found that people consider their religious beliefs before making purchasing decisions. This findings contradict earlier research as the previous findings showed that religious did not have a remarkable effect on customers' purchase intention in various section. Being Christian, Muslim, or Jewish, for example, had no bearing on the customers' preferences for unprocessed foods (fresh vs frozen chicken) (Heiman et. al, 2004). Furthermore, whether a customer is Protestant, Catholic, or Jewish, it has little bearing on their opinion of a store (McDaniel \& Burnett, 1990). These findings could imply that religious membership is inefficient in explaining a wide range of religious influences on consumer behaviour (Heiman et al., 2004). However, this study supports Muhamad and Mizerski's (2010) findings that religious devotion is one of the key factors that influences customers in the marketplace. Furthermore, religious devotion reflects how much a person sticks to firm and pragmatic principles that do not alter all that often (Khraim, 2010).

Analysis of the role of products and services provided by Starbucks also plays an important role in determining the purchase intention. This study discovered a moderately positive relationship between this element and purchase intention - if Starbucks' services 
and products are better, the likelihood of purchasing increases. Customer's orientation is also significantly correlated with purchase intention. Service provided by Starbucks that are based on customer's orientation will attract the customer to buy at the premises.

In the case of Starbucks, customers are willing to pay more for the products and services that they provide due to their strong reputation for dependability (Lee, 2007). The high quality of Starbucks product helps gain consumer's positive perception that contributes to the purchase of their product regardless the controversy regarding the halal issue. The strong reputation of Starbucks also will gain their consumers purchase intention as products and services is one of the strong corporate reputation elements (Feldman et al., 2014).

This study illustrates that customer's orientation had a positive and moderate correlation with purchase intention. This in line with Caruana et al. (2004) and Rose \& Thomsen (2004), as customer's outcome variables such as consumer's trust and loyalty have also been demonstrated to be positively influenced by corporate reputation (Caruana et al. 2004; Rose \& Thomsen 2004). Similarly, Terblanche (2014) highlighted that customer's orientation is positively associated to the customer's trust.

Nonetheless, the premise environment is one of the factors that attract customers to visit the premise. Based on the customer's perception of the Starbucks premise, it was found that the premise generates a positive feeling in people. Implications to generate positive feeling in these people, this study found that there is a moderate but significant positive relationship with purchase intention. Therefore, the more conducive the condition of the Starbucks premises, the greater the customer's desire to come to Starbucks. Strong positive emotion stated such as "good," "happy," "satisfied," and "amazing," according to Babin et al. (1994), can lead to greater time spent in the store, expenditure, and evaluations of liking for the store. Bitner (1992) discovered that positive moods resulted in more favourable store assessments and motivated customers to purchase more items. In contrast, finding from Tran, Nguyen, Melewar, and Bodoh (2015) reveals that even the customers have a great impression of certain products and believe that their employees are kind, it does not necessarily for the customer to go and purchase something from them because of the way the company conducts itself, but because of it expensive price.

Parallel to other variables, the leadership and innovation also had a positive and moderate correlation with purchase intention. Davies and Chun (2009) highlighted that the firm's leader serves as a primary source of information about the company, both internally to employees and internationally, to the media, local and national government, and, increasingly, to the general public and the company's consumers and potential customers. Organizations that establish and strengthen their corporate reputation model and intangible management process as part of their horizontal strategic planning will ensure their long-term success, leadership, and sustainability (Feldman et al., 2014).

In terms of ethical, consumers are more cautious when it comes to investing their hardearned money and they demand greater transparency and honesty (Leitch \& Motion, 2007). Consumers can express their acceptance or disapproval of a company's behaviour through the price they are willing to pay for its products. As a result, consumers may be ready to pay less for a product produced by a company that has acted unethically than for a similar product produced by a company that has acted ethically (Creyer, 1997). In relation to the results of ethical concern of this study, the findings from Creyer (1997) supports the view that the customers expect companies to conduct business ethically and that whether or not this 
is the case is an important concern. Consumers also report a willingness to reward ethical behaviour and punish unethical behaviour.

The results of social responsibility showed that it had a positive and moderate correlation with purchase intention. This lends empirical support to Gatti, Caruana, and Snehota (2012), who found that perceived CSR had a direct impact on corporate reputation and purchase intention. Another important element in corporate reputation is the leadership and innovation element. Studies show that there are positive and moderate relationship between these elements and purchase intention. It can be concluded that the customer's purchase intention is tied to how the internal elements of the organization such as the way Starbucks managing their premises. Innovative leadership will generate new ideas to create the appeal of the premises, hence attract the customers to come to their premises.

Customers also take into account the ethics that exist in a premise and in business dealings. They will continue to support and be with any ethical organization. This study found that when Starbucks practices transparent business ethics and follows every quality business principle, then customers will have more intention to purchase at their premises. These findings are significant. This support Gatti's et al. (2012) viewpoint on corporate social responsibility and corporate reputation that brand managers maintain a high level of ethical behaviour in their interactions with customers and in their overall pursuit of business goals. This ethical behaviour is likely to improve company reputation since they will predisposition customers to a brand, thus creating a desire to buy. Organizations that always emphasize on social responsibility will also encourage loyal customers to the organization. It was discovered that the more social responsibility customers contributed by Starbucks, the greater their purchase intention are, because this study gives the impression that there is a moderate and significant positive relationship between the study's enablers.

\section{CONCLUSION}

Corporate reputation is important for the company in order to gain more profits and success that defined the stabilization of their company in the future and also to compete with other companies in the same field of services. The purchase intention of consumers towards their products will contribute to the company's sale as well. Company has to know which elements of corporate reputation that will attract more consumers to their company to achieve their consumers' targets and also to communicate well with their consumers about the controversy that might affect customers' perception hence contribute to the consumers' purchase intentions whether to buy their products or not.

All the elements of Starbucks corporate reputation in this study including religious responsibility, products and services, customer's orientation, generating positive feeling in people, leadership and innovation, ethical and social responsibility maintained noteworthy relationship with purchase intention. All of these aspects must be emphasised in order for the company to be successful. The element of eliciting positive feelings in people confirms the strongest relationship with purchase intention, while religion displays the weakest. This demonstrates that customers are more concerned with emotion than religious elements. All of the elements of corporate reputation can be used to guide a company in elevating and improving its reputation. The company must communicate effectively with their customers about the controversies that may alter their perception, which will influence their decision 
to buy the products.

The usage of theory of planned behaviour in this study has the potential to improve people's perceptions and views of corporate reputation. The corporate reputation was considered within the theory of planned behaviour, and corporate reputation was seen as an attitude that have the direct impact on intention to perform a certain behaviour that turn to be the actual behaviour in this conceptualization. Considering corporate reputation as an attitude that leads to full-bodied view, more comprehensive theoretical understanding and also useful tool for a managerial response as stated by (Caruana, et al., 2006), more studies that emphasize attitudinal conceptualization and operationalization as mentioned by TPB model, is required.

Future research might expand the study to other premises or companies that operate the same or similar field of business as run by Starbucks. Thus, the importance of corporate reputation can be highlighted by the entrepreneur or businessman in order to successfully expand their business in the future. The elements of corporate reputation that contributed most to purchase intention could be investigated in depth in the future for extensive study. In this study, the researcher only focus on the customers of Starbucks and does not include the none customer.

For the future research, the none customer can be included in the study to determine the reasons why the corporate reputation do not create their purchase intention.

\section{REFERENCES}

Abdul Karim, K. A. (2010, August 5). Dilema kopitiam halal. Utusan Malaysia Online. Retrieved from http://www.utusan.com.my/

Abd. Razak, N. (2009, August 25). Tak patut timbul keraguan. Utusan Malaysia Online. Retrieved from http://www.utusan.com.my/

Ajzen, I. (1985). From intentions to actions: A theory of planned behaviour. In J. Kuhi \& J. Beckmann (Eds.), Action - control: From cognition to behaviour. (pp. 11- 39). Heidelberg: Springer.

Ajzen, I. (1991). The Theory of Planned Behaviour. Organizational Behaviour and Human Decision Processes, 50, 179-211. 10.1016/0749-5978(91)90020-T.

Astro Awani. (2014, December 11). Sijil Halal Starbucks tidak pernah ditarik balik: JAKIM. Bernama. Retrieved from: https://www.astroawani.com/berita-bisnes/sijil-halal-starbuckstidak-pernah-ditarik-balik-jakim-50107

Awan, H. M., \& Bukhari, K. S. (2011). Customer's criteria for selecting an Islamic bank: evidence from Pakistan. Journal of Islamic Marketing, 2 (1), 14-27.

Babin, B. J., Dardin, W. R., \& Griffin, L. A. (1994). Negative emotions in marketing research: Affect or artifact? Journal of Business Research, 42 (3), 271-285.

Balla, B. E., \& Ibrahim, D. S. (2014). Impact of corporate brand on customer's attitude towards repurchase intention. International Journal of Science and Research (IJSR) 3 (11) 2384-2388.

Bang, H., Odio, M.A., \& Reio, T. (2014). The moderating role of brand reputation and moral obligation. Journal of Management Development, 33, 282-298.

Berjaya. (n.d.). Berjaya Food Berhad. Corporate Profile. https://www.berjaya.com/berjaya- 
food/corporate-profile.php

Bitner, M. J. (1992). Servicescapes: The impact of physical surroundings on customers on customers and employees. Journal of Marketing, 56, 37-71.

Bronn, P. S. \& Vidaver-Cohen, D. (2009). Corporate motives for social initiative: legitimacy, sustainability, or the bottom line? Journal of Business Ethics, 87, 91-109.

Brown, T. J., Mowen J. C., Donovan, D. T. \& Licata, J. W. (2002). The customer orientation of service workers: personality trait effects on self and supervisor performance ratings. Journal of Marketing Research, 39, 110-119.

Brown, T. J. (1997). Comparing corporate reputations: League tables, quotients, benchmarks, or case studies?. Corporate Reputation review, 5(1), 35-50.

Carman, J. M. (1990) Consumer perceptions of service quality an assessment of the SERVQUAL dimensions. Journal of Retailing, 66, 33-55

Caruana, R., Munson, A., \& Niculescu-Mizil A. (2006). Getting the most out of ensemble selection. Proceedings of the $6^{\text {th }}$ International Conference on Data Mining (ICDM'06). Hong Kong.

Chang, T. L. S., \& Zhu, W. (2011). Enhancing corporate reputation for market expansion in China: customer orientation and the mediating effect of product and service quality. Journal of Strategic Marketing, 19(02), 153-170.

Creyer, E. H. (1997). The influence of firm behavior on purchase intention: do consumers really care about business ethics? Journal of Consumer Marketing, 14 (6), 421-432.

Cronin, J. J. Jr., Brady M. K., \& Hult, T. M. (2000). Assessing the effects of quality, value and customer satisfaction on behavioural intentions in service environment. Journal of Retailing, 76(2), 193-218.

Cukur, C. S., De Guzman, M. R. T., \& Carlo, G. (2004). Religiosity, values, and horizontal and vertical individualism -Collectivism: A study of Turkey, the United States, and the Philippines. The Journal of Social Psychology, 144(6), 613-634.

Davies, S. (1999). Stubborn disparities: Explaining class inequalities in schooling. In J. Curtis, E. Grabb, \& N. Guppy (Eds.), Social inequality in Canada: Pat terns, problems, and policies (3rd ed., pp. 138-150). Scarborough, ON: Prentice-Hall Canada.

Davies, G., \& Chun, R. (2009). The leader's role in managing reputation. In Klewes J., Wreschniok R. (eds), Reputation capital (pp. 311-323). Berlin, Heidelberg: Springer.

Department of Statistic Malaysia. (2017). Department of Statistic Malaysia Official Portal. Retrieved from https://www.dosm.gov.my/v1/index.php?r=column/ctwoByCat\&parent id=115\&menu_id=L0pheU43NWJwRWVSZklWdzQ4TlhUUT09

Din, M. A., Loo, W., Kumar, A., \& Lim, K. T. (2016, May 29). A case study on Starbucks influencing Malaysian coffee drinkers and their lifestyles. Seminar in Marketing and Global Business. Universiti Sains Malaysia: Penang. Retrieved from https://www. academia.edu/25568953/A_case_study_on_Starbucks_influencing_Malaysian_coffee_ drinkers_and_their_lifestyles

Dodds, W. B., Monroe, K. B., \& Grewal, D. (1991). Effects of price, brand, and store information on buyers' product evaluations. Journal of Marketing Research, 28 (3), 307-319.

Doney, P. M., \& Cannon, J. P. (1997). An examination of the nature of trust in buyer-seller relationships. Journal of Marketing, 61, 35-51.

Duriez, B., Soenens, B., \& Beyers, W. (2004). Personality, identity styles, and religiosity: 
An integrative study among late adolescents in Flanders (Belgium). Journal of Personality, 72(5), 877-910.

Dutton, J. E., Dukerich, J. M., \& Harquail, C. V. (1994). Organizational images and member identification. Administrative Science Quarterly, 39(2), 239-263. https://doi.org/10.2307/2393235.

Eid, R. (2015). Integrating Muslim customer perceived value, satisfaction, loyalty and retention in the tourism industry: An empirical study. International Journal of Tourism Research, 17(3), 249-260.

Esch, F. R., Langer, T., Schmitt, B. H., \& Geus, P. (2006). Are brands forever? How brand knowledge and relationships affect current and future purchases. Journal of Product $\mathcal{E}$ Brand Management, 15(20), 98-105.

Essoo, N. \& Dibb, S. (2004). Religious influences on shopping behaviour: Aan exploratory study. Journal of Marketing Management, 20, 683-712. doi:10.1362/0267257041838728

Feldman, P. M., Bahamonde, R. A., \& Velasquez, B. I. (2014). A new approach for measuring corporate reputation. Revista de Administração de Empresas, 54, 53-66.

Fishbein, M. \& Ajzen, I. (1975). Belief, attitude, intention and behaviour: An introduction to theory and research. Reading, MA: Addison-Wesley.

Fombrun, C. J. (1996). Reputation: realizing value from the corporate image. Harvard Business School: Boston.

Fombrun, C., \& Shanley, M. (1990). What's in a name? Reputation building and corporate strategy. Academy of Management Journal, 33, 233-258. 10.2307/256324.

Fombrun, C. J., Gardberg, N. A., \& Sever, J. W. (2000). The reputation quotient: a multistakeholder measure of corporate reputation. The Journal of Brand Management, 7 (4), 241-255.

Gatti, L., Caruana, A., \& Snehota, I. (2012). The role of corporate social responsibility, perceived quality and corporate reputation on purchase intention: Implications for brand management. Journal of Brand Management, 20(1), 65-76.

Goi, C. L. (2013). Factors influencing customers to visit coffee chains. World Review of Business Research, 3(4), 172-183.

Gotsi, M. \& Wilson, A. M. (2001). Corporate reputation: Seeking a definition. Corporate. Communiation. International. Journal, 6, 24-30.

Gray, E. R., \& Balmer, J. M. T. (1998). Managing corporate image and corporate reputation. Long Range Planning, 31(5), 695-702. https://doi.org/10.1016/S0024-6301(98)00074

Grebe, K. (2013). Things can get worse: How mismanagement of a crisis response strategy can cause a secondary or a double crisis. The example of the AWB corporate scandal. Corporate Communications: An International Journal, 18 (1), 70-86.

Hamzah, Z. (2010, July 27). Sisi gelap kopitiam - logo asli tapi palsu. Utusan Malaysia Online. Retrieved from http://www.utusan.com.my/

Hashim, N., Ruslan, N., \& Haque, M. (2015). Lifestyle diseases and their association with coffee consumption at Ipoh, Malaysia. Research Journal of Pharmacy and Technology (RJPT), 8, 285-291. 10.5958/0974-360X.2015.00048.7.

Heiman, A., McWilliams, B., \& Zilberman, D. (2004). Religious, religiosity, life style and the food consumptions. Journal of Food Quality and Preferences, 8, 9-11

Helm, S. (2005). Designing a formative measure for corporate reputation. Corporate Reputation 
Review, 8(2), 95-109.

Herbig, P. \& Milewicz, J. (1993). The relationship of reputation and credibility to brand success. Journal of Consumer Marketing, 12 (4), 5-11.

Jaafar, S. N., Lalp, P. E., \& Naba, M. M. (2012). Consumers' perceptions, attitudes and purchase intention towards private label food products in Malaysia. Asian Journal of Business and Management Sciences, 2(8), 73-90.

JAKIM. (2010, Dec 11). Why “Halal Malaysia'?. The Star. https://www.thestar.com.my/opinion/ letters/2010/12/11/why-halal-malaysia

Johnson, M. D., Herrmann, A., \& Huber, F. (2006). The evolution of loyalty intentions. Journal of Marketing, 70(2), 122-132.

Joseph C. J. J., Brandy, M. K. \& Hult, G. T. M. (2000). Assessing the effects of quality, value, and customer satisfaction on consumer behavioural intentions in service environments. Journal of Retailing, 76 (2), 193-218.

Juhl, H. J., Kristensen, K. \& Ostergaard, P. (2002). Consumer satisfaction in European food retailing. Journal of Retailing and Consumer Services, 9(6), 27-34.

Kang, G. D., \& James, J. (2004). Service quality dimensions: An examination of Gronroos's service quality model. Managing Service Quality, 14(4), 266-77.

Kang, J. W., \& Namkung, Y. (2018). The effect of corporate social responsibility on brand equity and the moderating role of ethical consumerism: The case of Starbucks. Journal of Hospitality \& Tourism Research, 42(7), 1130-1151.

Keh, H. T., \& Xie, Y. (2009). Corporate reputation and customer behavioural intentions: The roles of trust, identification and commitment. Industrial Marketing Management, 38(7), 732-742. doi:10.1016/j.indmarman.2008.02.00

Khraim, H. (2010), measuring religiosity in consumer research from an Islamic perspective. Journal of Economic and Administrative Sciences, 26 (1), 52-78. https://doi. org/10.1108/10264116201000003

Kotler, P. (2000). Consumer market and consumer behaviour. Principles of Marketing, (8th ed.). Upper Saddle River, NJ: Prentice-Hall,

Krejcie, R. V., \& Morgan, D. W. (1970). Determining sample size for research activities. Educational and Psychological Measurement, 30, 607-610.

Latiff, A. Z., Rezai, G., Mohamed, Z. \& Ayob, M. (2015). Food labels' impact assessment on consumer purchasing behaviour in Malaysia. Journal of Food Products Marketing, 22, 1-12. 10.1080/10454446.2013.856053.

Lau, S. (1989). Religious schema and values. International Journal of Psychology, 24(1-5), 137-156.

Lee, S. (2007, November 19). Are Starbucks' prices too high? Customer Think. Retrieved from https://customerthink.com/are_starbucks_prices_too_high/.

Leitch, S. \& Motion, J. (2007). Retooling the corporate brand: A Foucauldian perspective on normalisation and differentiation. Journal of Brand Management, Vol. 15 (1), 71-80.

Lian, D. (2011, August 8). Starbucks counters non-halal claim. Marketing-Interactive. Retrieved from: https://www.marketing-interactive.com/starbucks-counters-non-halal-claim-over$\mathrm{fb}$.

Ljubojevic, C. \& Ljubojevic, G. (2008). Building corporate reputation through corporate governance. Management, 3(3), 221-233.

Logsdon, J. M., \& Wood, D. J. (2002). Reputation as an emerging con-struct in the business 
and society field: An introduction. Business \& Society, 41(4), 365-370.

Maiyaki, A. A. (2013). Principles of Islamic capital market. International Journal of Academic Research in Accounting, Finance and Management Sciences, 3(4), 278-283.

McDaniel, S. W., \& Burnett, J. J. (1990). Consumer religiosity and retail store evaluative criteria. Journal of the Academy of marketing Science, 18(2), 101-112.

Morgan, R. M. \& Hunt, S. D. (1994). The commitment-trust theory of relationship marketing. Journal of Marketing, 58 (3), 20-38.

Mohamed, Z., Rezai, G., Shamsudin, M. N., \& Chiew, E. F. C. (2008). Halal logo and consumers' confidence: What are the important factors. Economic and Technology Management Review, 3(1), 37-45.

Monirul, I. M., \& Han, J. H. (2012). Perceived quality and attitude toward tea \& coffee by consumers. International Journal of Business Research and Management (IJBRM), 3(3), 100-112.

Muhamad, N., \& Mizerski, D. (2010). The constructs mediating religions' influence on buyers and consumers. Journal of Islamic Marketing, 1 (2). 124-135. https://doi. org/10.1108/17590831011055860.

Ong, J. (2014). Do coffee addicts pay the price in Malaysia? Free Malaysia Today. Retrieved from http://www.freemalaysiatoday.com/category/leisure/2014/03/07/docoffee-addicts-pay-the-price-in-msia/.

Pappu, R., Quester, P. G., \& Cooksey, R. W. (2005). Consumer-based brand equity: Improving the measurement-empirical evidence. Journal of Product \& Brand Management, 14(3), 143-154.

Parasuraman, A., Zeithaml, V. A. \& Berry, L. L. (1998). Servqual: A multiple-item scale for measuring consumer perception. Journal of Retailing, 64(1), 12-40.

Ramos-González, M., Rubio-Andrés, M., \& Sastre-Castillo, M. Á. (2017). Building corporate reputation through sustainable entrepreneurship: The mediating effect of ethical behaviour. Sustainability, 9(9), 1663. Retrieved from https://www.mdpi.com/20711050/9/9/1663/htm

Reichheld, F. F., \& Sasser, W. E. (1990). Zero defections: Quality comes to service. Harvard Business Review, 68(5), 105-11.

Rettab, B., Brik, A. \& Mellahi, K. (2009). A study of management perceptions of the impact of corporate social responsibility on organisational performance in emerging economies: The case of Dubai. Journal of Business Ethics 89(3), 371-390.

Roberts, S. (2003). Supply chain specific? Understanding the patchy success of ethical sourcing initiatives. Journal of Business Ethics, 44(2), 159-170.

Rose, C. \& Thomsen, S. (2004). The impact of corporate reputation on performance: some Danish evidence. European Management Journal, 22 (2), 201-210. 10.1016/j. emj.2004.01.012.

Samad, A. (2014). Examining the impact of perceived service quality dimensions on repurchase intentions and word of mouth: A case from software industry of Pakistan. IOSR Journal of Business and Management, 16, 37-41.

Saxe, R. \& Weitz, B.A. (1982). The SOCO Scale: A measure of the customer orientation of salespeople. Journal of Marketing Research, 19 (3), 343-351.

Saxton, M. K., (1998). Where do corporate reputation come from? Corporate Reputation 
Review, 1(4), 393-399.

Schifman, L. G., \& Kanuk. L. L. (2009). Consumer behaviour. England: Prentice Hall.

Shachar, R., Erdem, T., Cutright, K. M., \& Fitzsimons, G. J. (2011). Brands: The opiate of the nonreligious masses?. Marketing Science, 30(1), 92-110.

Shamma H. M. \& Hassan S. S. (2015) Customer-driven benchmarking: A strategic approach leading to sustainable performance. In: Robinson, Jr. L. (eds) Marketing dynamism $\mathcal{E}$ sustainability: things change, things stay the same...: Proceedings of the academy of marketing science, (pp. 533-533). Bazel: Springer, Cham. https://doi.org/10.1007/978-3-319-10912$1 \_176$

Sharom, N. F. M. (2019, September 3). Isu 'Starbucks haram' sengaja diulang di media sosial. Sinar Harian. https://www.sinarharian.com.my/article/46197/BERITA/Nasional/ Isu-Starbucks-haram-sengaja-diulang-di-media-sosial.

Sibthorpe, J. (2009) A review of corporate reputation: 12 steps to safeguarding and recovering reputation. Journal of Business \& Finance Librarianship, 14(3), 300-302, doi: $10.1080 / 08963560802450925$

Singh, J., \& Del Bosque, I. R. (2008). Understanding corporate social responsibility and product perceptions in consumer markets: A cross-cultural evaluation. Journal of Business Ethics, 80(3), 597-611.

Sisson, D. C., \& Bowen, S. A. (2017). Reputation management and authenticity: A case study of Starbucks' UK tax crisis and "\# SpreadTheCheer" campaign. Journal of Communication Management, 21 (3), 287-302. https://doi.org/10.1108/JCOM-06-2016-0043

Spreng, R. A., \& Page, Jr. T. (2001). The impact of confidence in expectations on consumer satisfaction. Psychology and Marketing, 18(11), 1187-1204. https://doi.org/10.1002/mar.1049

Starbucks News Room. (2018, January 19). Starbucks names fifth most admired company worldwide. https://stories.starbucks.com/stories/2018/starbucks-fortune-most-admiredcompany-in-the-world/

Terblanche, N. S. (2014). Validation of the customer-based corporate reputation scale in a retail context. International Journal of Market Research, 56(5), 655-671.

Tran, M. A., Nguyen, B., Melewar, T. C., \& Bodoh, J. (2015). Exploring the corporate image formation process. Qualitative Market Research: An International Journal.

Van der Laan, G., Van Ees, H. \& Van Witteloostuijn, A. (2008). Corporate social and financial performance: An extended stakeholder theory, and empirical test with accounting measures. Journal of Business Ethic, 79(3), 299-310.

Walsh, G., \& Beatty, S. E. (2007). Customer-based corporate reputation of a service firm: Scale development and validation. Journal of the Academy of Marketing Science, 35(1), 127-14. http://dx.doi.org/10.1007/s11747-007-0015-7

Weigelt, K., \& Camerer, C. (1988). Reputation and corporate strategy: A review of recent theory and applications. Strategic Management Journal, 9(5), 443-454.

Yaacob, Z. (2014). The link between quality management and Muslim customer satisfaction. International Journal of Business \& Society, 15(1).

Yee, C. P., Mun, K. W. K., Yee, L. M., \& Ling, Y. (2014). Factors influencing purchase intention of Starbucks (Unpublished Doctoral dissertation), UTAR.

Yoon, E., Guffey, H. J., \& Kijewski, V. (1993). The effects of information and company 
reputation on intentions to buy a business service. Journal of Business Research, 27(3), 215-228.

Yoon, S., \& Suh, H. (2004). Ensuring IT Consulting SERVQUAL and user satisfaction: A modified measurement tool. Information Systems Frontiers, 6(4), 341-51. 